Peer review: This article has been subject to a double blind peer review process

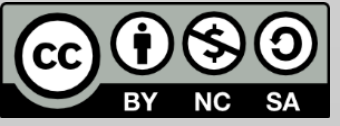

(C) Copyright: The Authors. This article is issued under the terms of the Creative Commons Attribution NonCommercial Share Alike License, which permits use and redistribution of the work provided that the original author and source are credited, the work is not used for commercial purposes and that any derivative works are made available under the same license terms.

\section{Brasiguaio Identities: An outcome of the pursuit of land across the Brazilian and Paraguayan shared border region}

\author{
Marcos Estrada* \\ Centre for Interdisciplinary Methodologies, University of Warwick \\ *Correspondence: m.estrada@warwick.ac.uk
}

\begin{abstract}
The movement of people between places is far from being a new or isolated phenomenon and is happening more often than before. This is also the case for individuals who moved from Brazil to Paraguay. Based on the existing literature as well as on data gathered in the landless camp Antônio Irmão, also known locally as the 'Brasiguaios landless camp' in Itaquiraí in the state of Mato Grosso do Sul, Brazil, this article explains how their search for a piece of land in either Brazil or Paraguay influenced the formation of the Brasiguaios identities. First, I briefly approach the foundation of transnationalism scholarship, which guided my research. Next, I demonstrate how land policies in Brazil and Paraguay, aimed at developing their respective border regions, played a role in the migration of Brazilians to Paraguayan and then the return of a number of them to Brazil. Last, I share the narrative of individuals in the Brasiguaio landless camp in the pursuit of land in either country. At the core of my argument is that the Brasiguaio identities of this landless group result from their pursuit of land rather than from migration processes.
\end{abstract}

Keywords: migration; borders; transnationalism; Brazil; Paraguay; Brasiguaios

\section{Introduction}

Migration is far from being a new or isolated phenomenon, and individuals are increasingly moving from their place of birth. The movement of people, goods and information, especially since the last century, has acquired unprecedented dimensions in the twenty-first century. According to the United Nations Population Fund, 244 million people live outside their country of birth (UNFPA, 2017). This number is likely to be an underestimate as it excludes those who have immigrated illegally as well as groups living in proximity to their country of origin, a number of whom often falsely claim to be residents of their country of 
origin to profit from welfare benefits, which is the case of many Brazilian immigrants living in Paraguay (Estrada, 2015).

In the modern world, political borders have been crucial in presenting the movement of people between countries. The movement of people across borders has been in the interest of not only individuals seeking to socially and economically benefit from more than one country but also in the interest of policy-makers and researchers. As an area of academic enquiry, the field of transnationalism was grounded on the analysis of 'processes by which immigrants forge and sustain multi-stranded social relations that link together their societies of origin and settlement' (Glick Schiller et al., 1994: 7). Since Glick Schiller and her colleagues established the field of transnationalism in the 1990s, this field has rapidly evolved. While the phenomenon became better understood, it has presented new challenges to researchers in the field of study. Recently, scholars such as Strüver (2005), Kopinak and Soriano Miras (2013) and Estrada (2015) have demonstrated that non-migrants, as well as migrants, living within bordering communities, have engaged in transnationalism without the need to migrate. Hence, there is a need, for instance, to expand the transnationalism scholarship by focusing on the transnational processes themselves rather than devoting attention to processes carried by immigrants only.

There is ample evidence suggesting that transnationalism is not a new phenomenon; the field of transnationalism has long demonstrated that it is not only immigrants who create and maintain ties involving two or more countries. The movement of people, goods and services across nation-states dates back to the time when the means of travel and communication were expensive and accessed by few people (Portes, 2001). At the same time, especially in the field of border studies, scholars demonstrated that borders, territories and individuals' identities are not congruent. This argument was present in my doctoral research Everyday Practices of Transnational Living: Making Sense of Brasiguaio Identities, in which I argued that both immigrant as well as non-migrant groups have engaged in different forms of transnational practices; hence, the existence of diverse Brasiguaio identities. In this particular case of Brasiguaios in the landless camp Antônio Irmão, I demonstrate that the formation of Brasiguaio identities result from people's aspiration to have a piece of land for agricultural production. In the years of 2013 and 2014, I lived for approximately four months in this landless camp.' Based on data gathered from two multi-sited ethnographies carried as part of my $\mathrm{PhD}$ research, I show that Brasiguaios have their identities grounded on the pursuit of land. 


\section{The conceptual articulation of Brasiguaio identities}

The word Brasiguaio is a combination of the words Brazilian + Paraguayan, in Portuguese brasileiro + paraguaio $=$ Brasiguaio, also spelt in Spanish as Brasiguayo (brasileño + paraguayo). "ii The formation and representation of Brasiguaio identities were grounded and have been widely perceived within the scholarly community as an outcome of the mass migration of Brazilians to Paraguay, as if the migration process by itself had led to the formation of Brasiguaios. Yet, scholars have studied different groups holding socio-cultural ties in Brazil and Paraguay (e.g. Nickson, 1988; Nogueira and Silva, 2008; Marques, 2009; Albuquerque, 2010; Vuyk, 2013).

Migration was at the core of the studies on Brasiguaios when it acquired force in the 1990s, and continued in the second wave of studies on this group that has rapidly increased since the 2000s. The earliest conceptual articulation, presented by the Brazilian anthropologist Sprandel (1992), referred to Brasiguaios as Brazilian immigrants who did not economically succeed in Paraguay. Sprandel's work is still important and widely used by researchers with focus on the mass migration of Brazilians to Paraguay, especially between the 1960s and 1970s, to explain the formation of the Brasiguaio identities. However, further studies have demonstrated Brasiguaio identities in different contexts. Despite the important contributions of these works, they focused upon the Brazilian migrants living in Paraguay, paying limited attention to individuals of Paraguayan origin, Brazilian returnees from Paraguay living in Brazil, and local inhabitants living within the shared border region of both countries.

The second wave of researchers interested on Brasiguaios appeared after 2000 , and literature on this group has rapidly increased since then. Conducting research according to their different areas of expertise, a number of researchers have gone on to identify Brasiguaios living in Paraguay as well as those returnees living within the Brazilian and Paraguayan border region as being part of this distinct group of Brazilian migrants. In Brazil, these researchers include Albuquerque (2010), Colognese (2012), Dietrich (2004); Nogueira and Silva (2008), Marques (2009), to mention a few. In Paraguay, researchers also have interest in this group and use the term Brasiguaios when referring to Brazilian migrants living and working in agricultural production in Paraguay (Fogel and Riquelme, 2005; Mongelós, 2006; Nickson, 1988; Palau and Heikel, 1987; Vuyk, 2013).

Commonly, Brazilian scholarship uses the term Brasiguaio referring to both the Brazilian peasants and small farmers who immigrated to Paraguay after failing to thrive in Brazil; and those who returned to Brazil after failing to thrive in Paraguay. In Paraguay, the term commonly refers 
to wealthy Brazilian immigrants and their descendants, usually large soybean producers. In both countries, despite the evidence that many self-defined Brasiguaios are engaged in agricultural production or in the pursuit of land, the focus is still on their migration processes. To define a Brasiguaio is problematic because the term has taken on a variety of meanings, often contradictory and renegotiated over time, to indicate how the group members strategically navigate their lives through their journeys, usually in the pursuit of land, within Brazil and Paraguay.

\section{Land policies and the migration of Brazilians to Paraguay}

The development of the border region through agriculture was at the core of the dictatorships in Brazil and Paraguay, 1964-1985 and 19541989, respectively. The national land policies created separately in Brazil and Paraguay to develop their respective border regions had a 'push-pull' effect in both countries. In Brazil, domestic land policies seeking to populate the poorly inhabited central-western part of Brazil began to be implemented during the mandate of the Brazilian president Getúlio Vargas (1930-1945). As a strategy to stimulate migration from other regions of Brazil, Vargas put in place a series of land policies known as Marcha para o Oeste (March to the West). The main objective was to develop the centre of Brazil, and the state of Mato Grosso iii [do Sul], on the limit with Paraguay. Those policies were instrumental in attracting peasant and small farmers from other parts of Brazil, who would later migrate to Paraguay. The Brazilian government had two economic justifications for their interest in populating that region. Firstly, as those regions had fertile soil, it would be economically beneficial to develop commercial agriculture in them. Secondly, the Brazilian government seek reinforce its sovereignty by populating its border region with Paraguay, which had been demarcated in 1872 .

To develop those regions, Vargas' government first attracted the Nordestinos (Northeasterns) peasants especially from the impoverished states of Bahía, Paraíba and Pernambuco in the northeast region of Brazil. Nordestinos were a group mainly comprised of ethnically mixed Europeans, Amerindians and African descendants. This region had experienced severe drought and economic difficulties since the 1930s that would last until the 1980s. Thus, the Nordestinos were relatively eager to emigrate from that region. Vargas and his successors subsequently implemented strategies to attract the Sulistas (southerners) from the south of Brazil. The Sulistas were comprised largely of European descendants. To attract them to engage in agricultural practice in Paraguay, the government emphasised the fertile soil, abundance of 
water and climatic conditions similar to the conditions found in the south of Brazil.

Later, in the 1950s, the Brazilian president Juscelino Kubitscheck (19561961) continued Vargas' programme to populate the border region with Paraguay, which had been unsuccessful at creating favourable conditions for them to develop agriculture in the central-western part of Brazil, near Paraguay.

While some land programmes failed to stimulate migrants to remain in the region, other programmes developed mechanised modes of production that drastically reduced the number of people required for agricultural production (Cortêz, 1993; Tiburcio, 2011). As result of the failed land programme in the Brazil, attracted by Paraguayan land policies to attract Brazilian migrants to develop its border region, a number of Brazilians in the central-western region moved to Paraguay.

During the same period, the construction of the binational Itaipú hydroelectric dam (1974-1983) on the border between Brazil and Paraguay, which flooded a part of both countries, would later contribute to the migration of Brazilians to Paraguay. The construction of the lake on the border between Brazil and Paraguay forced the displacement of 42,000 people, 38,000 of whom were small farmers (Albuquerque, 2010: 66). The total of Brazilians who migrated to Paraguay as result of the construction of the Itaipú hydroelectric dam is uncertain. A number of small farmers who had their land displaced by the construction of the dam migrated to Paraguay after receiving compensation, where land was much cheaper and very fertile.

Overall, the momentum created by unsuccessful national land programmes in Brazil to resettle peasants and small farmers from other regions of the country, and the construction of the binational Itaipú hydroelectric dam that forced some farmers to leave the area, along with Paraguayan land policies seeking to attract Brazilians to Paraguay, resulted in a mass migration of Brazilians to Paraguay.

\section{Land policies in Paraguay as incentives for attracting Brazilian migrants}

In 1952, the Chief of the Paraguayan army at the time, General Alfred Stroessner, gave the Brazilian Geremias Lunardelli, known as 'Cattle King' in the Brazilian state of Paraná, the concession of 450,000 hectares of land in Paraguay (Cortêz, 1993: 17). Later, while Brazil was struggling to resettle agricultural workers in the central-western region of the country, General Alfred Stroessner came into power in Paraguay after leading an 
army coup in 1954 (1954 -1989). At the time, the fertile land of the eastern region of Paraguay was still mostly covered by its natural vegetation. Until the 1960 s, this region was one of the last suitable places remaining in South America for intensive agricultural development (Tiburcio, 2011: 191-192). Stroessner introduced a series of policies to attract Brazilians to the departments of Alto Paraná, Canindeyú and Amambay on the eastern side of Paraguay through the development of agriculture.

In the 1960s, General Stroessner planned a series of policies known as Marcha al Leste (March to the East). Stroessner's first strategy was to attract Brazilians by promoting land sale to Brazilians through colonizadoras (Brazilian private companies based in Brazil, selling land in Paraguay). At the beginning of the 1960s, colonizadoras advertised in Brazil that: 'with the sale of one alqueire ${ }^{\text {iv }}$ [of land] in Brazil, it would be possible to buy more than five [alqueires of land] in Paraguay,' with the Paraguayan government financing the initial investment to prepare the land (Wagner, 1990: 16). Since that time, Brazilians only need to request a permiso (permit) on the border when entering Paraguay for no more than 90 days.

As not all crossing points had migration offices, and most Brazilians had the intention to remain in the country for longer than stipulated period, most of them simply did not apply for the permiso, or applied once and then lived illegally in Paraguay. In some cases, they would apply for a new permiso each time they visited Brazil, and the frequency of their visits to Brazil depended on their work and personal circumstances and could happen very sporadically. This avoidance was because there was a fee to renew the permiso, which many people could not afford. In the past, there were many Brazilians officially counted as tourists living within Paraguay, who just regularly renewed their permiso (Albuquerque, 2010).

In 1963, the Paraguayan government passed the laws 852/63 and 854/63, creating the Instituto de Bienestar Rural (Institute of Rural Welfare) and the Estatuto Agrario (Agrarian Statute), respectively. Law 852/63 created the Institute of Rural Welfare to promote colonisation (Paraguay, 1963a), land reform and oversight of the land use. Law 854/63 created the Agrarian Statute to stimulate and guarantee that rural properties were carrying out their social function (Paraguay, 1963b). According to this law, rural properties accomplish their social function if the exploitation and use of the land proved rational, and if the conservation and recuperation of the land were observed.

In 1967, the Stroessner regime passed a new constitution making significant changes to the law, one of which was the abolition of the national law prohibiting foreign nationals from purchasing land in the 
country. This excerpt from an interview with Adilson, a migrant who returned from Paraguay to Brazil in 2012 and now lives in the landless camp Antônio Irmão, gives evidence of the efficacy of Paraguay's land policies:

I went to Paraguay in 1972... Brazilians who went to Paraguay had relatives or friends there, any small amount [of money] was a lot on the other side... by selling 1 hectare in Brazil, you could buy 10 or 15 hectares, depending on the region, or even more, so, it was easy to buy farms and more farms; thus, the region developed very fast. (Adilson, Brazilian, 50 [Paraguay, 40], 2012)

According to Cortêz, the Brazilian president Geisel (1974-1979) had aimed to occupy $121.889 \mathrm{~km}^{2}-33$ per cent of the territory of Paraguay with 1,200,000 Brazilians, which would make up approximately 45 per cent of the Paraguayan population at the time (Cortêz, 1993: 188-199). Although this alleged occupation never happened, the Brazilian presence is very significant in Paraguay. Any figure from either country regarding the stock of Brazilian migrants in Paraguay and their place of origin is still subject to discussion. The table below provides an estimate of the extent of the migration of Brazilians to Paraguay.

Table 1: Stock of Brazilian Migrants in Paraguay

\begin{tabular}{|c|c|c|c|c|c|c|c|}
\hline Year & 1943 & 1956 & 1962 & $\mathbf{1 9 6 9}$ & $\mathbf{1 9 7 2}$ & $\mathbf{1 9 7 9}$ & $\mathbf{1 9 8 2}$ \\
\hline Total & 513 & 636 & 2,250 & 11,000 & 31,869 & 150,000 & 250,000 \\
\hline \multicolumn{7}{|l|}{} \\
\hline Year & $\mathbf{1 9 8 5}$ & $\mathbf{1 9 8 6}$ & $\mathbf{2 0 0 0}$ & $\mathbf{2 0 0 1}$ & $\mathbf{2 0 0 2}$ & $\mathbf{2 0 1 2}$ & $\mathbf{2 0 1 4}$ \\
\hline Total & 500,000 & 350,000 & 454,501 & 442,104 & 459,147 & 500,000 & 600,000 \\
\hline
\end{tabular}

Source: Author's elaboration using data from Laino (1979), Wagner (1990), Última Hora (2003), Marques (2009), Albuquerque (2010), Tiburcio (2011), Lissardy (2012), Simon (2013), Fiorentin (2013) and Stiftung (2014).

Giving that the latest figure estimates 600,000 individuals of Brazilian origin merely in the eastern side of Paraguay, any figure is likely to underestimate the actual numbers and complexity of the migration processes of Brazilians to Paraguay. They may leave out the groups of migrants living in remote areas who are excluded from official statistics, along with migrants who were visiting Brazil at the time when the data was gathered. Although it is unlikely that the existing data provide accurate figures, they indicate the extent to which land policies in both countries influenced the migration of Brazilians to Paraguay. 


\section{The return in the pursuit of land in Brazil, as Brasiguaios}

In the 1980s, the Brasiguaios identity group gained visibility in Paraguay being (re)presented as the Brazilian immigrants in Paraguay. By 1985, tensions grew between immigrants of Brazilian origin, now known as Brasiguaios, and Paraguayan landless groups, resulting in conflicts over land ownership that led to the return of a large number of families of Brazilian origin from Paraguay to Brazil. This group only gained visibility and became known when a group of about 1000 families of Brazilian origin returned overnight from Paraguay to the Brazilian bordering of Mundo Novo, in the state of Mato Grosso to Sul, on 14 June 1985. Their plight was widely reported in Brazil, also as far as in the United Kingdom (Rocha, 1985). Those individuals returned from Paraguay upholding the Brasiguaio identity demonstrated that identities were not constrained within boundaries, but are a fluid process that can be assimilated, reproduced and altered through time and territory. In the words of Pratt and Yeoh, identities are 'contradictory and complex, and must be assessed at specific times and places' (Pratt and Yeoh, 2003:259).

According to Albuquerque (2010), the return of Brazilians from Paraguay was led by the promise of agrarian reform in Brazil, which was made by the presidential candidate José Sarney, who governed Brazil from 1985 to 1990. Despite his promise of settling 1.4 million landless families during his mandate, he only settled 90 thousand families (Palhares, 2011). The return was organised with the support of the office for the Serviço Pastoral do Migrante - SPM (Pastoral Care of Migrants ${ }^{\mathrm{vi}}$ ) in Paraguay through contacts in Brazil, members of the Office for the Serviço Pastoral do Migrante of the town of Foz do Iguaçu, in Brazil, and representatives of the MST (Albuquerque, 2010). Those circuits are complexly formed and involved a variety of actors. According to Hannerz, various historical sources of culture are differentially visible and active, and they take the shape of a 'continuous spectrum of interacting meanings and meaningful forms' (1996: 67). Despite these self-defined Brazilians having the support of different organisations, their return was problematic. Paulo, who returned to Brazil in 2010, explained:

Since the 1980s, people say we are Brasiguaios because we came here [to Brazil]. There is no problem because we are really Brasiguaios, but it is not nice because people look and think, 'they are poor people who came here to ask the government for a piece of land because they are Brazilians. Even so, we will say we are Brasiguaios, so people know we were expelled from Paraguay. (Paulo, Brazilian, 38, [Paraguay, c.25], 2010)

Paulo's narrative gives evidence of their landless condition. In this fragment, besides reinforcing their rights as Brazilians, they upheld their 
status as Brasiguaios to differentiate themselves as a distinct group from the rest of Brazilians by showing allegiance to Brazil and Paraguay; individuals have demonstrated loyalty to two or more countries (Fitzgerald and Waldinger, 2004: 1181). Liisa Malkki (1992) argues that as human mobility increases, individuals create identities through memories from different places, including places where they have lived but will not be able to live in again.

As points out by Massey (2005), every representation is a representation of a time and space; it only exists in context. The Brasiguaio strategy produced results in 1985, and the Brasiguaios were settled by the Brazilian National Institute for Colonization and Agrarian Reform (INCRA) in record time in the city of Ivinhema (Sprandel, 1992), which was later emancipated and became the town of Novo Horizonte Sul, also in the state of Mato Grosso do Sul, about 200 kilometres away from Mundo Novo.

The mass return from Paraguay to Brazil of individuals claiming to be Brasiguaios and struggling for agrarian reform is still remembered and celebrated in the young municipality of Novo Horizonte do Sul. The representation of Brasiguaios, built upon the idea of migration and pursuit of land in Brazil, was seen in the celebration of the $19^{\text {th }}$ anniversary of Novo Horizonte do Sul on 30 April 2011. The celebration included a play enacted by pupils from the local school presenting the arrival and mobilisation of Brasiguaios in the town of Mundo Novo in 1985, which had led to the establishment of their current home (Resende, 2011). Recently, in June 2017, schools in Novo Horizonte do Sul celebrated the $32^{\text {nd }}$ anniversary of the settlement of the self-defined Brasiguaios who returned from Paraguay to Brazil on 14 June 1985 (Valemsnews, 2017). As Sprandel (1992) pointed out long ago, when referring to this group, the mobilisation in the pursuit of land entrenches in the collective memory of these Brasiguaios (36). Both celebrations demonstrate that the migration process and return, as well as the movement between both countries, had become markers of their Brasiguaio identity.

\section{The Antônio Irmão landless camp of Brasiguaios}

The landless camp Antônio Irmão, vii known as 'Brasiguaios landless camp' is part of the Brazilian Rural Workers' Landless Movement (MST). In Brazil, landless people build landless camps, sprawling villages of tarp tents usually built in the area meant for the construction of federal highway shoulders, which belongs to the government, and then start to demand a piece of land for farming from the Brazilian government. The landless 
camps are built near a highway due to two main reasons. Firstly, it is public land, so the likelihood - although possible - of eviction is low. Secondly, they want to be seen by society; to stay by a highway is their strategy to be seen by the media. Media, therefore, not only serves for presenting everyday reality but also contributes to confirming, creating and recreating the identities (Prado, 2005: 3). Below, pictures 1 and 2 show the aerial view of the landless camp and a part of the landless camp, respectively.

Figure 1: Location of the landless camp Antônio Irmão

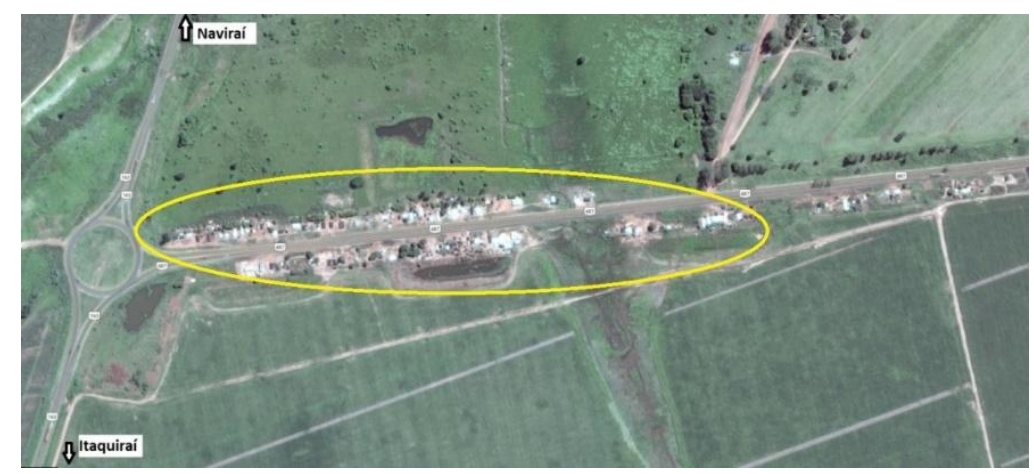

Source: Author's elaboration using Google maps. The landless camp is the white and black tarp tents which the area marked in yellow.

Figure 2: Landless camp Antônio Irmão

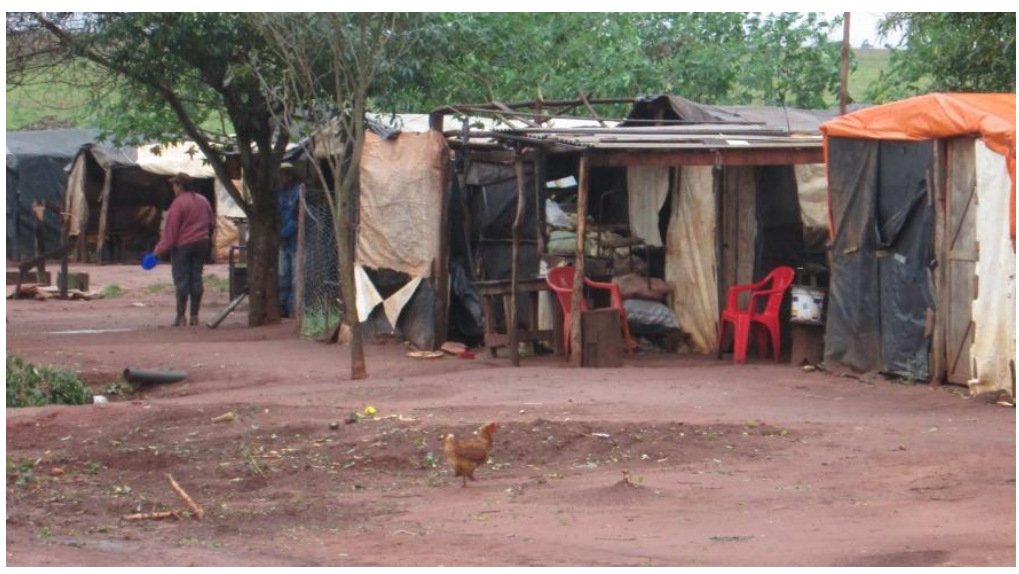

Photo by the author. This is a part of the landless camp Antônio Irmão.

This landless camp was created in 2001, but it grew in size and gained visibility in the media with the arrival of the self-defined Brasiguaios. In 2009, as a result of political changes and the intensification of the MST's advocacy work in Paraguay assisting in the return of families of Brazilian origin from Paraguay, this landless camp had up 612 families. As pointed 
out by Adão, a MST's member who did not live in Paraguay but carried out advocacy in Paraguay said:

Maybe, they made an agreement; it is a joke what I am saying, but nobody knows: Let's send those Brazilians to work over there [in Paraguay], after about 50 years, when we think it is enough, send them back [to Brazil]. (Adão, Brazilian, 45)

Adão's joke may be real. Wagner (1990) suggested that the migration of Brazilians to Paraguay was perceived by landless groups as a meticulously planned agreement between Brazil and Paraguay to develop agricultural production within the border regions. Whether or not they constituted a plan of agreement between both countries, Brazilian and Paraguayan land policies were planned and implemented over time as if these governments came up with these policies separately. The Paraguayan government's objective was clear: to have highly-skilled Brazilian farmers. This objective was achieved. Land policies, along with cheap land and economic incentives, attracted a large number of Brazilians to Paraguay. As the Brazilian government was unable to resolve the agrarian issues in Brazil, the migration of Brazilians to Paraguay was seen by the Brazilian government as a positive alleviation of internal land problems.

Although some Brazilians and their descendants became responsible for most of the soybean production in Paraguay over the years, not all of them managed to economically succeed in that country and some needed support to return. The MST in the State of Mato Grosso do Sul supported the return of Brasiguaios because 'many of its militants and leaders are Brasiguaios, who returned from the neighbouring country [Paraguay]' (Moraes and Costa Vieira, 2015: 375). This is seen in the narrative of João, who explained that:

There are people who have resources, and want to return to Brazil, but if they sell all they have in Paraguay, they cannot afford a piece of land in Brazil. So, the way to do it is through agrarian reform. This is what motivates these people to join a landless camp. (João, Brazilian, 27 [Paraguay, 15], 1999)

Many other residents in the landless camp shared a similar narrative. In some cases, they explicitly said they had no preference to be in either Brazil or Paraguay, as long as they could have a piece of land; this is because, as João said in another moment, 'Brasiguaios have roots in both countries'. Jaime further explained:

We were all working together in Paraguay, some people returned, some people stayed, but we are all working with land. We came before to get land, but we are Brasiguaio too and we are a part of 
the MST, so we help them. Maybe, they will help others in the future. (Jaime, Brazilian, 42 [Paraguay, 17], 2009)

As Jaime explained, militants in the landless movement have supported the returned of Brasiguaios because they are also both Brasiguaios and members of the MST, which the MST started to assist this group before it was formed in 1984. The MST-MS has assisted the return of Brasiguaios from Paraguay to demand their Brazilian constitutional rights to property (Brasil, 1988). It is seen that decisions made at the national levels are significant to the practice of grassroots organisations and variations in the constitution; new laws have drawn noteworthy attention from migrants' offspring toward the country of their ancestors' (FernandezKelly, 2015: 303).

The MST-MS has provided strategic support for poor Brazilian returnees from Paraguay to resettle and, therefore, to exercise their citizenship rights in Brazil. As a social movement that mobilises landless rural workers to demand land from the Brazilian government, by assisting in the return and settlement of individuals coming from Paraguay to Brazil, the MST-MS has helped to establish the noteworthy and meaningful condition of landlessness as a part of the Brasiguaio identity.

\section{Concluding remarks}

The pursuit of land in Paraguay, and later in Brazil, grounded the formation of the Brasiguaio identities of individuals living in the landless camp Antonio Irmão. Migration was an outcome, a result of their pursuit of land in both countries, rather than their objective. At first, Brazilian peasants and small farmers migrated within Brazil to develop the Brazilian border region with Paraguay through agricultural production, and later were attracted to Paraguay. The pursuit of land in Paraguay was, in part, led by the creation of Paraguayan land policies, especially in the 1960s and 1970s, along with the construction of the Itaipú hydroelectric dam, which expropriated a number of farmers and peasants in the Brazilian.

The second push in the consolidation of the Brasiguaio identities happened with the return of a large number of Brazilian immigrants from Paraguay to Brazil, in 1985, along with their descendants, when they were expelled from their land in Paraguay, and sought land in Brazil. The foremost remark is that the establishment of Brasiguaio identities, broadly speaking, has been guided by their desire to have a piece of land in either country and, at the same time, creating socio-cultural ties in both Brazil and Paraguay. 
' I previously visited the landless in 2012 , which was very important to obtain permission to stay in the landless camp in the subsequent years. In 2015, I visited the landless for a week to give an update on the process of my research and share with them information about the conferences where I had presented my research about them, so I would not leave any negative aspects behind, as other researchers had left before me. In 2016, although I had not planned, while I was visiting Brazil, I travelled to visit the landless camp for two days. ii Although Brasiguaio is not a recognised nationality or ethnic group, respecting this self-defined and/or attributed category as a distinct group from Brazilian and Paraguayans, I use capital ' $b$ ' when writing about this group in the English language.

iii Today's state of Mato Grosso Sul came into existence in 1977 with the division of the state of Mato Grosso into two: Mato Grosso and Mato Grosso do Sul ${ }^{i v}$ The alqueire is a unit of measure for the distribution of productive land used in Brazil since the time the country was a colony of Portugal; it is still widely used and is the equivalent of 2.42 hectares.

${ }^{v}$ When citing excerpts from interviews, I use the following system: Pseudonym of the respondent, country of citizenship, age at the time of the interview, years living in Paraguay and year of return to Brazil.

vi The Serviço Pastoral do Migrante is an arm of the Catholic Church, created in 1984 , and officially established in 1986, with the objective is to assist migrants at the local and national level.

vii The documentary Brasiguaios: Transnational Lives and Identities provides information about this identity group. Further information is available in its official website www.brasiguaios.com.

\section{List of Tables}

Table 1: Stock of Brazilian Migrants in Paraguay.

\section{List of Illustrations}

Figure 1: Location of the landless camp Antônio Irmão.

Figure 2: Landless camp Antônio Irmão. 


\section{References}

Albuquerque, J. (2009), 'A Dinâmica das Fronteiras: Deslocamento e Circulação dos 'Brasiguaios' entre os Limites Nacionais', Horizontes Antropológicos, 31, 137-166

Albuquerque, J. L. (2010), A Dinâmica das Fronteiras: Os brasiguaios na Fronteira entre o Brasil e o Paraguai, São Paulo: Annablume

Blanc, J. (2015), 'Enclaves of Inequality: Brasiguaios and the Transformation of the Brazil-Paraguay Borderlands', The Journal of Peasant Studies, 42 (1), 145-158

Brasil (1988), Constituição da República Federativa do Brasil, http://www.planalto.gov.br/ccivil 03/constituicao/constituicao.htm, accessed 22 June 2017

Colognese, S. A. (2012), 'Brasiguaios: uma Identidade na Fronteira Brasil/Paraguai', Tempo da Ciência, 19 (38), 145-158

Cortêz, C. (1993), Brasiguaios: Os Refugiados Desconhecidos, Campo Grande -MS, Brazil: Agora

Dietrich, W. (2004), 'Os Brasiguaios no Brasil Aspectos Fonéticos e Gramaticais', in Dietrich, W. and V. Noll (eds.), O Português e o Tupi no Brasil: Frankfurt, pp. 147-154

Estrada, M. (2015), The Impact of Land Policies on International Migration and Transnational Practices: The Case of the Brasiguaios. Working Paper Series, p. 17, International Migration Institute, http://www.imi.ox.ac.uk/publications/the-impact-of-land-policies-oninternational-migration-the-case-of-the-brasiguaios, accessed 22 July 2017

Fernandez-Kelly, P. (2015), 'Assimilation through Transnationalism: A theoretical Synthesis', in Portes, A., and P. Fernandez-Kelly (eds.), The state and the grassroots: Immigrant transnational organizations in four continents. New York - Oxford: Berghahn Books, pp. 291-318

Ferrari, C. A. (2009), Dinâmica Territorial na (s) Fronteira (s): Um Estudo sobre a Expansão do Agronegócio e a Exploração dos Brasiguaios no Norte do Departamento de Alto Paraná-Paraguai, Dissertação de Mestrado, Universidade Federal da Grande Dourados (UFGD)

Fiorentin, M. I. S. (2013), 'Imigrantes Brasileiros Radicados no Paraguai: Dilemas Identitários e Hibridismo Cultural', Revista Paraguay desde las Ciencias Sociales, 2, 81-96

Fitzgerald, D., and R. Waldinger (2004), 'Transnationalism in Question', American Journal of Sociology, 109 (5), 1177-1195 
Fogel, R., and M. Riquelme, (2005), Enclave Sojero: Merma de Soberanía y Pobreza, Asunción: CERI

Glick Schiller, N., L. Basch and C. S. Blanc (1994), Nations Unbound: Transnational Projects, Postcolonial Predicaments, and Deterritorialized Nation-States, Amsterdam: Gordon and Breach Publishers

Hannerz, U. (1996), Transnational Connections: Culture, People, Places, London and New York: Routledge

Kopinak, K. and R. M. Soriano Miras (2013), 'Types of Migration Enabled by Maquiladoras in Baja California, Mexico: The Importance of Commuting', Journal of Borderlands Studies, 28 (1), 75-91

Laino, D. (1979), Paraguay: Fronteiras y Penetración Brasileña, Asunción: CERRO CORA

Lissardy, G. (2012). Paraguay: Los 'brasiguayos', La Voz del Nuevo Gobierno para Seducir a Brasil, BBC News, http://www.bbc.co.uk/mundo/noticias/2012/06/120627 paraguay crisis franco lugo brasil brasiguayos jg.shtml, accessed 17 June 2017

Malkki, L. (1992), 'National Geographic: The Rooting of Peoples and the Territorialization of National Identity among Scholars and Refugees', in Eley, G., and R. G. Suny (eds.), Becoming National: A Reader, New York: Oxford University, pp. 24-44

Marques, D. H. F. (2009), 'Circularidade na Fronteira do Paraguai e Brasil: O Estudo de Caso dos "Brasiguaios" unpublished PhD thesis, Cedeplar/UFMG

Massey, D. (2005), For Space, Oak, CA: Sage

Mongelós, L. E. V. (2006), 'JST Portavoz de la Violencia Sufrida por los Brasiguayos un Fenómeno Social Ignorado por Dos Países: Análisis del periodo 1985-1986', unpublished master dissertation, Universidad Católica Nuestra Señora de la Asunción

Moraes, I. A. d., and , F. A. de Costa Vieira (2015), 'Capitalismo Agrário e os Movimentos Campesinos no Paraguai', Revista Estudos Históricos, 28 (56), 363-384

Nickson, R. A. (1988), 'Tyranny and longevity: Stroessner's Paraguay', Third World Quarterly, 10 (1), 237-259

Nogueira, V. M. R., and M. G. Silva (2008), 'Brasiguaios: A Dupla Desigualdade na Região da Fronteira', in Costa, L. C. (ed.), Estado e Democracia: Pluralidade de Questões, São Paulo/Ponta Grossa: UEPG, pp. 153-170 
Palau, T., and M. V. Heikel (1987), Los Campesinos: El Estado u las Empresas em la Frontera Agrícola, Asunción: BASE/PISPAL

Palhares, I. (2011), O modo como se pensa a divisão da terra, ComCiência, http://comciencia.scielo.br/scielo.php?script=sci arttext\&pid=S151976542011000900006\&lng=es\&nrm=iso, accessed 22 July 2017 Portes, A. (2001), 'Introduction: The Debates and Significance of Immigrant Transnationalism', Global Networks, 1 (3),181-194 Pratt, G., and B. Yeoh (2003), 'Transnational (counter) Topographies', Gender, place and culture: A Journal of Feminist Geography, 10 (2), 159166

Resende, G. (2011), Novo Horizonte do Sul Revive sua Origem da Reforma Agrária, Novo Horizonte do Sul-MS, http://www.geraldoresende.com.br/ imprensa/noticias/novo-horizonte-do-sul-revive-sua-origem-da-reformaagraria, accessed 20 June 2017

Rocha, J. (1985), 'Brazilian Farmers Flee Paraguayan Victimisation', The Guardian, p. 4

Simon, R. (2013), Brasiguaios Apoiam Volta de Colorados no Paraguai, São Paulo-SP, Brazil: O Estado de S. Paulo, http://internacional.estadao.com.br/noticias/geral,brasiguaios-apoiamvolta-de-colorados-no-paraguai-imp-,1020605, accessed 20 June 2017

Smith, M. P. (1994), 'Can You Imagine? Transnational Migration and the Globalization of Grassroots Politics', Social Text, (39), 15-33

Sprandel, M. A. (1992), 'Brasiguaios: Conflito e Identidade em Fronteiras Internacionais', unpublished master dissertation, Universidade Federal do Rio de Janeiro

Bertelsmann Stiftung (2014), 'Paraguay Country Report', in Bertelsmann Stiftung BTI 2014, Gütersloh: Bertelsmann Stiftung

Strüver, A. (2005), Spheres of Transnationalism within the European Union: On Open Doors, Thresholds and Drawbridges along the DutchGerman Border. Journal of Ethnic and Migration Studies 31 (2), 323-343.

Tiburcio, J. (2011), 'Brazilians in Paraguay: A Growing Internal Problem or a Regional Issue?', in Kemp, W., V. Popovski, and R. Thakur (eds.), Blood and Borders: The Responsibility to Protect and the Problem of the KinState. Tokyo -New York- Paris: United Nations Press.

Última Hora (2003), 'La Invasión Brasileña', Última Hora, 17 September 2003, p. 4 
UNFPA (2017), United Nations Population Fund,

http://www.unfpa.org/migration, accessed 20 June 2017

Valemsnews (2017), Escolas realizam desfile cívico em comemoração ao 32ㅇ Aniversário de Assentamento de Novo Horizonte do Sul, Novo Horizonte do Sul: ValemsNews, www.valemsnews.com.br/noticias/item/ 1189-escolas-realizam-desfile-civico-em-comemoracao-ao-32aniversario-de-assentamento-de-novo-horizonte-do-sul, accessed 21 June 2017

Vuyk, C. (2013), Subimperialismo Brasileiro y Dependencia Paraguaya: Análisis de la Situación Actual, http://biblioteca.clacso.edu.ar/gsdl/collect/clacso/index/assoc/D8967.dir VuykTrabajoFinalCLACSO2013.pdf, accessed 21 June 2017

Wagner, C. (1990), Brasiguaios: Homens sem Pátria, Petrópolis-RJ, Brazil: Voz

\section{To cite this article:}

Estrada, M. (2017). Brasiguaio Identities: An outcome of the pursuit of land across the Brazilian and Paraguayan shared border region. Exchanges: the Warwick Research Journal, 5(1), 41-57. Retrieved from:

http://exchanges.warwick.ac.uk/index.php/exchanges/article/view/205 